\title{
医 学書誌と図書節利用
}

現代の広汎な知識世界飞於て, 研究成果を 上げるためには, 図書利用の正しい理解が重 要条件である。ここに紹介する本は，乙の条 件を容易にする一助として発行されたもので ある。

Medizinische Bücherkunde und Bibliotheksbenutzung: ein Grundriss für Studierende und Ärzte, von Gottfried Kricker; 3. Aufl. Leipzig: J. A. Barth. 1954. S. 68. DM 3. 90.

I. 序言：医学図書利用を妨げる二つの原因 がある。第一は, 医学研究にとつて, 図書は 僅少な価値の久を有するとの意見である。圭 る委ど観察と実験は, 自然科学就中医学にと つて重要なととであるが，科学は多くの知識 の綜合によつて大成するものであるから，関 連する文獻の蒐集が必要となる。第二は, 医 学文獻の多種多量なととである。専門家でさ え, 專門領域の新しい出版物を完全に見通す ことは困難である。図書館は索引, 目録, 畫 誌等を準備して, 研究を推進する。

II. 医学畫誌と図書館の歴史：医学書がどの よらに世界に伝播して行つたかは, 又医学発 展史でもある。パリ大学, ハイデルベルヒ大 学, ケルン大学, ウィーン大学等艺の初期 には，たつた 10 冊前後の図書を蔵していた に過ざない。後印刷術の発明が急速に図書と 図畫館を普及させ，種々の書誌類が作られる よらになつた。

III.，医学図書館の組織：医学図書館の対象 は図書である。図書诂外的形式によつて, 単 行本一全集と雑誌——撖書の 2 種に分け, 多くの図書館は乙れらを別々に扱い，それぞ れ一般閲覧室と雑誌閲覽室とがある。単行本 全集と雑誌一一叢書はさらに，それぞれ 内容に従つて分類整理する。この分類は学術 分類と原理的に一致する。百科事典, 辞典, 資 料, Handbuch, Lehrbuch, 書誌類, 抄録雑 誌等の参照的図畫は,すぐ手にとれるよう,一 般閲覧室に配置する。とれらに対しそれぞれ 目録力ードがある。この他, 出納所があり, 図
書貸出，返納の质か，らろんろの相談に応ず る。

IV. カード目録：図書館運営の重点はカー ド目録に就かる。それ故，カードにどんな 事項が記入され，又カードはどのよらに排列 されるか等の規則を知るととが大切である。 著者名目録，件名目録，分類目録等の特徵は 何か，その他種々の目録についての知識は図 書利用の鍵となり，図書の分類体系に通じる か, 通じないかは文獻探索の能率に影響する。 V. 医学畫誌：医学書誌も多くの種類があ り，これらの特徵を知るととが望ましい。抄 録雑誌はよく利用される有益な書誌である。 或る文獻が自己の研究に必要であるかを予知 するため, 科学的進歩の概観を得るため, 文 獻の不備欠点を調查するため等に利用する。 その他書誌類似のもの：Handbuch, Lehrbuch，伝記，医学会議又は協会文獻索引，大 医学図書館目録，博士論文書誌，專門雑誌索 引等も文獻蒐集の有用な手掛である。

VI. 医学書誌と図書館利用：科学研究を始 めるに当つて，まず文獻の予備的調査をする のが定石である。研究問題の歴史的発展, 基 礎概念を知るため, Handbuch 或は Lehrbuch を読んで見る。次いで，種々の書誌を利用し て, 文獻を根気よく蒐集する。勿論平常, 専 門雑誌に注意し，鋭い見識を養らことが肝心 である。レフアレンスを集めるのに普通カー ドを使用し，カード記入事項——雑誌名省略 法，巻号頁数その他一一は標準がある。こ れらは論文を作製する時の材料になる。

VII. 附録：図書館はいかに秩序づけられて いるか?: 図書館の作業過程を理解するとと は，各自が文獻整理の仕事をする時，大いに 役立つ。ことには図書館の仕事が順を追つて 具体的に略述されている。

本誌特集の 1952 年再版された L. T. Morton: How to use a medical library $と$ 併 読すれば，両者補足し合い，得るところが多 らと思う。

谷山高美 *

* 大阪市立医大阊畫館 